\title{
THAILAND
}

\section{Thaksin Survives Yet Disquiet Floods the Kingdom}

\author{
Nicholas Farrelly
}

During 2011 the unresolved legacies of recent political conflict continued to overshadow prospects for reconciliation in Thailand. The pivot for the current troubles is the coup of 19 September 2006 when the army leadership, in concert with palace insiders, deposed the electorally successful government of Prime Minister Thaksin Shinawatra. ${ }^{1}$ The coup was designed to dismantle the Thaksin juggernaut and eradicate his supposedly malign, even dictatorial, influence from national life. The worry, both then and now, is that Thaksin can disrupt the careful plans - economic, political, royal, etc. - of other factions among the country's elite. Thaksin, with his telecommunications fortune and unique track record of marshalling electoral support, has been portrayed as the enemy of national unity. Since the coup there have been more than five years of jousting between Thaksin and his allies, on the one hand, and senior members of the military, Privy Council, judiciary, and bureaucracy on the other. In 2011 the ghosts of the 2006 extra-constitutional intervention, and the ineptitude and violence that followed, returned to haunt the coup makers. With the 2011 election there is a final popular verdict on the coup and its aftermath. It is a bleak one for those who had worked towards Thaksin's downfall.

Remarkably, Thaksin has survived. With the Pheua Thai Party's resounding election victory on 3 July 2011, and its leadership of the country's new coalition government, his ignominious exile from Thailand, and from official political activities, may be coming to an end. All efforts to purge him have failed. By a large margin, Thaksin remains the most electorally successful politician in the country's history and the events of 2011 reinforce his singular claim to a popular

Nicholas Farrelly is a Research Fellow in the School of International, Political and Strategic Studies, College of Asia and the Pacific, the Australian National University. 
mandate. ${ }^{2}$ With the triumph of his sister, Prime Minister Yingluck Shinawatra, Thaksin is once again in a decisive position. And while Yingluck is commonly described as a "political novice", ${ }^{3}$ and many doubt her abilities, ${ }^{4}$ she has proved a very effective proxy for Thaksin and his brand of politics. The conundrum now facing Thaksin's political opponents is that their policies and personalities, as represented by the Democrat Party and the New Politics Party, among other party political movements, do not garner widespread electoral support. In 2011 even the quirky "vote no" campaign of the hard line anti-Thaksin groups failed to make much of an impression. ${ }^{5}$ The strength of Thaksin's base in the rural provinces of the north and northeast, but also in the predominately working class areas on Bangkok's periphery, is clear. Efforts to stigmatize him have largely failed. ${ }^{6}$ The evidence from 2011 is that support remains robust for Thaksin personally and more broadly for the brand of populism, and patronage, he represents. ${ }^{7}$

Nonetheless, the role of anti-Thaksin military, royal, judicial, and bureaucratic networks is a complicating factor. While they may enjoy only modest popular support for their political agendas, these institutions are potentially powerful centres for undermining the Pheua Thai-led government and its electoral success. The army chief, General Prayuth Chan-ocha, and senior palace officials, such as the Privy Council chairman, General Prem Tinsulanonda, among others, are deeply enmeshed in efforts to neuter Thaksin's influence. ${ }^{8}$ They remain wary of Thaksin, speak out against his corrupt and disruptive history, and likely harbour an appetite to challenge him again in the years ahead. In this context, soon after the 2011 election Singapore-based political analyst Pavin Chachavalpongpun went so far as to argue that "[i]t is time for Madame Prime Minister to act like a true soldier - fire the one [General Prayuth] who has caused great damage to Thai interests." Yingluck has yet to take that advice and one explanation for her hesitancy is that the freedom of action of senior military figures is greatly diminished by the electoral support she commands. Furthermore, since the violent crackdown on Thaksin-aligned Red Shirt protestors in April-May 2010 (when ninety-one people were killed), both the palace and the army have been increasingly targeted for their anti-democratic tendencies. ${ }^{10}$ Any future political interventions outside the electoral and parliamentary process (what Thais often call nok rabob) would risk generating even more significant conflict in what is already a profoundly disquieted society.

The year 2011 ends, however, with a different preoccupation. There is a huge clean-up, rehabilitation, and reconstruction effort under way after the devastating floods that covered large portions of the country in the period July-November. This crisis has shaped the early public perception of Yingluck's government, which 
has only been in power since August. In the context of the Pheua Thai Party's election victory, and the optimism that followed, the floods are a major setback. In response, there is already speculation that a significant Cabinet reshuffle, and the re-entry of politicians banned from high office after the 2006 coup, is planned for 2012. ${ }^{11}$ Meanwhile, the relative strengths and weaknesses of factions among the Thai elite are muddied by the response to the floods: all sides have been openly criticized for perceived inadequacies. Through this watery prism we can reflect on recent developments in Thai politics, foreign relations, and military matters, and must also consider the looming royal succession. Even though the year saw little political violence in Bangkok, the country remains primed for further conflict. There were, with this in mind, few positive developments around the most explosive issues facing Thailand: the simmering conflict in the southernmost provinces and the role of the royal family after King Bhumibol Adulyadej dies.

\section{Election 2011}

To begin the year, the government of Prime Minister Abhisit Vejjajiva - which came to power in December 2008 when it benefited from a judicially mandated dissolution of the Thaksin-aligned People Power Party - remained equivocal about the timing of an election to determine a new government. ${ }^{12}$ Smouldering indications from top military circles suggested that alternative paths, including entirely nonelectoral ones, were possible. Prime Minister Abhisit was naturally seeking a viable way to continue in power after weathering the tumult of April-May 2010 when his government teetered on the brink of collapse during violent demonstrations in central Bangkok. However, his Democrat Party is historically weak at the ballot box and has only won once since the advent of regular democratic elections in 1992. Many Democrat Party critics rejoice in explaining that it has lost the last six elections in a row. Once the election was announced, the army chief, General Prayuth, encouraged Thais not to choose the "same" politicians and advised that they should instead opt for "good people". ${ }^{13} \mathrm{He}$ clearly had Prime Minister Abhisit on his list of "good people" but the general's advice was widely ignored.

The seven-week election campaign, from May to July 2011, which pitted Abhisit against Yingluck, was fiercely contested across the length and breadth of the country. Yingluck began with very little political campaigning experience: it was only on 16 May, one week after the election was called, that she was even made the Pheua Thai Party's top-ranked party list candidate. ${ }^{14}$ During the campaign she was attacked for this perceived inexperience and her lack of earlier interest in national political issues. However, she quickly gained a level of respect for 
her campaigning in traditional pro-Thaksin strongholds in the rural north and northeast. The prospect of electing Thailand's first female Prime Minister also helped her cause.

Crucially, during the campaign there was no effort to imply that Yingluck would govern independent of her brother's ambitions. Instead, Thaksin's strategists worked diligently to insist that Yingluck represented the style of electorally successful politics, sometimes referred to disparagingly as "populist", which was the hallmark of the pre-coup, Thai Rak Thai era. ${ }^{15}$ The striking family resemblance to Thaksin never hurt her chances. And in the all-important rural constituencies where the spoils of political power are decided, she appeared comfortable and relaxed. Going into the 2011 poll Yingluck, and her supporters, took some confidence from the fact that in the 2001, 2005, and 2007 elections they had out-performed all of their political opponents. Their only defeats in the past decade came through non-electoral mechanisms: military and judicial interventions.

For that reason the election of 2011 cannot be viewed as a purely political contest. It was also a contest to further define the history of the post-coup period, especially the bitter episodes of violent street confrontation. In 2008, 2009, and 2010, Thailand experienced violence around the street mobilizations of the Red Shirt (largely pro-Thaksin) and Yellow Shirt (implacably anti-Thaksin) political movements. It was the Red Shirts that felt the wrath of the 2010 crackdown by Thai security forces under the command of General Prayuth and Prime Minister Abhisit. Determining responsibility for that violence, and perhaps punishing those considered to have acted with excessive force, has become a core demand for Red Shirt activists.

In the context of this long-running social conflict, and his irretrievably damaged reputation as one of Thailand's rare "clean-skin" politicians, Abhisit failed to present a strong enough alternative. His economic policies wilted in the face of Yingluck's aggressive, populist tendencies. During the campaign, she sought to reintroduce the pro-poor policies which are widely considered the hallmark of Thaksin-style politics. Even where both Abhisit and Yingluck were calling for similar approaches, such as an increase to the minimum wage, Pheua Thai took a consistently more radical line. It was therefore not surprising when the early results on 3 July suggested a landslide for Yingluck. The final result was not quite as stark but, nonetheless, Pheua Thai became only the second political party in Thai history to win a majority sufficient to govern independent of any coalition partners. It won 265 seats, while the Democrat Party could only manage 159. In terms of the overall vote, Pheua Thai garnered 15,744,190 and the Democrats 11,433,762. Abhisit's message of continuity and stability failed 
to convince the millions of voters who remained loyal, in 2011, to the political juggernaut of Thaksin Shinawatra. Within days a new coalition government had been configured, bringing Pheua Thai into an arrangement with four other parties to command 296 of the 500 seats in parliament.

\section{Foreign Relations}

These domestic political events had ramifications in terms of Thai foreign policy. In 2011 Thailand's foreign relations were defined by two very different governments. For the first half of the year foreign policy under Prime Minister Abhisit was punctuated by violent confrontation with Cambodia, and the ongoing effort to track Thaksin around the world spearheaded by Foreign Minister Kasit Piromya. The brinksmanship with Cambodia, which was centred on the disputed border demarcation around the ancient Preah Vihear temple complex, led to a significant breakdown in the bilateral relationship. Early in the year there were a number of clashes between the security forces of the two countries. These left around forty dead. For the Abhisit government, such a showdown served the associated purpose of highlighting the reputedly close ties between former Prime Minister Thaksin and Cambodian Prime Minister Hun Sen. ${ }^{16}$ The conflict with Cambodia was a grave concern to those who worried it would be used to justify yet another military intervention in Thai politics. Thailand's ultra-nationalists, especially remnants of the faded Yellow Shirt street movement, hoped, perhaps naively, that due to the conflict with Cambodia the Abhisit government would be forced to resign. Some anticipated a hard line military caretaker regime taking control to punish the Cambodians and to more vigorously wage the ongoing battle against Thaksin. However, Thai foreign policy did not ultimately have any such impact on the custodianship of political power.

With her resounding domestic mandate, Yingluck has, since the election, largely prioritized national issues. To be fair, the most pressing problems, especially the flood crisis, have not merited much international dealing. Yingluck's first international trip, in September, was to Brunei Darussalam. However, late in the year she did travel abroad on a number of other occasions. In December she met with Myanmar's pro-democracy figurehead, Aung San Suu Kyi, as well as the country's President, Thein Sein. Pictures of Aung San Suu Kyi and Yingluck standing in front of a portrait of King Bhumibol were presented in newspapers around the world. She has also enjoyed brief audiences with the leaders of other Southeast Asian nations, including Indonesia, Vietnam, Cambodia, and Laos. In some quarters, Yingluck has been criticized for "her poor command of the English 
language"; in terms of foreign policy acumen, unflattering contrasts with Prime Minister Abhisit have been made. ${ }^{17}$

\section{Post-poll Politics}

Certainly there are those who miss Abhisit's gentle eloquence and natural flair for international politics; Yingluck (and Thaksin) will never match him in that regard. After his defeat, Abhisit addressed the Thai people as outgoing Prime Minister with an eye to history's verdict. In a conciliatory speech, but one which included key stanzas designed to defend his actions over the past years, he insisted that "[t]he general election under our parliamentary system is another step forward in Thailand's democracy. It is aimed to move our county towards reconciliation." ${ }^{18}$ Then, on 5 August, a month after the election, the new parliament voted to install Yingluck as Thailand's twenty-eighth Prime Minister. ${ }^{19}$ In her first policy statement to parliament she set out short- and long-term goals, and set a different tone to Abhisit. For Yingluck's new government the most urgent policies were fostering reconciliation, suppressing corruption, promoting integrated water management, accelerating efforts to restore peace in the three southernmost provinces, and promoting cooperation with neighbouring countries. ${ }^{20}$ Yingluck emphasized the need to provide economic support because of inflationary pressures and invoked Thai Rak Thai-era policies such as increasing the availability of credit to farmers. Moreover, her Cabinet included close Thaksin allies such as Police Captain Chalerm Ubumrung (Deputy Prime Minister) and Police General Kowit Wattana (Deputy Prime Minister). The Minister of Foreign Affairs, Surapong Tovichakchaikul, and the Minister of Defence, General Yuthasak Sasiprapha, are also both long-term Thaksin backers. ${ }^{21}$

This effort to bring experienced officials and ministers, and old Thaksin, allies, into the government dampened some of the most serious criticisms of Yingluck and her team. Considerable effort was made to present a coherent and attractive policy platform, and to introduce a well-regarded senior leadership team. Given the multitude of political challenges facing the country, Yingluck requires their counsel. But even this team struggled in the face of the events that swiftly followed their election to power.

The flood crisis in the second half of 2011 tested Yingluck, Thaksin and Pheua Thai in ways they may not have expected. Unusual levels of precipitation throughout 2011 meant that at the peak of the wet season huge amounts of water flowed through northern and central Thailand. Flooding in fifty-eight provinces caused significant disruption, especially in areas such as Ayutthaya, where large 
parts of the country's manufacturing sector are based. Complaints about the government's handling of this difficult period have been as obvious as they have been inevitable. ${ }^{22}$ This disrupted period, unwelcome for the Yingluck government, caused months of consternation and developed into another opportunity for political point-scoring. The government's handling of the floods was widely criticized, especially by those who are naturally unsympathetic to Thaksin-style politics. In many areas government assistance was reportedly almost non-existent and what resources were available were quickly diminished by the overwhelming demand. To compensate for this perceived inaction, Yingluck opted not to attend the Asia Pacific Economic Cooperation Summit held in the United States in November, citing the floods crisis. High-powered committees were also established to help with the flood relief effort, and by October and November the government was better mobilizing personnel and supplies to help those affected. Since the flood waters receded during November the reconstruction phase has seen continued political manoeuvring and jousting. Yingluck has promised compensation for those impacted by the floods. The management of such handouts will become another battleground in the year ahead.

\section{Economic Resilience}

In the context of the disruptions caused by recent political conflict, Thailand's economy has remained relatively strong. Forecasts for 2011 were, at the start of the year, quite positive. These suggested that Thailand would be in a position to grow at more than 3.5 per cent. ${ }^{23}$ By the end of the year, this was downgraded to 1 per cent. ${ }^{24}$ This modest number follows a growth rate of 7.8 per cent in 2010 , a contraction of -2.3 per cent in 2009 , and growth of 2.5 per cent in 2008. Overall, the Thai economy has proven quite resilient in the face of domestic political turmoil. Tourist arrivals have remained strong and in 2011 a record of over 18 million foreigners visited the country. ${ }^{25}$ And given global economic jitters since 2008, Thailand's performance has, in these years, proven robust. In recognition of this economic strength, in July 2011 the World Bank upgraded Thailand from a lower-middle-income country to an upper-middle-income country. It now joins Malaysia as the second Southeast Asian economy in that category.

Nonetheless, 2011 saw a number of other economic challenges, some of which will remain important for years to come. The first challenge was the devastating earthquake and tsunami in Japan. This served to undermine the prospects of one of Thailand's key trading partners. It led to a contraction in the Thai economy in the second quarter of the year. ${ }^{26}$ The disruption of global automobile supply 
chains was especially challenging at that time. The second significant economic calamity in 2011 accompanied the floods. These were most destructive in the central plains, especially in the heavily industrialized province of Ayutthaya. Agricultural production was also hit hard. The full economic impact of the floods will not be known for some time. The challenge is to manage a rapid recovery, especially in the globally important, supply-change focussed elements of Thailand's economy. New investment in flood mitigation efforts may ultimately help to generate a steep spike in economic growth. Such investment will no doubt be fiercely contested at the level of national politics.

In 2011 the election campaign emphasized a long list of economic topics, including increasing the minimum wage, investing in major infrastructure projects, lowering corporate taxes, and reintroducing a rice mortgage policy. Even though Thailand has continued its strong performance for most of the past four years, there is widespread popular trepidation about the country's prospects. Economic issues remain electorally potent, and on the campaign trail they may have been decisive. Both the Pheua Thai and Democrat parties endeavoured to appeal to the interests of voters struggling to maintain living standards with rising prices. The legacy of the earlier Thai Rak Thai-era, when Thailand's economy experienced a sustained boom, has not been forgotten. As a result, the CEO-style policies associated with the Shinawatra family still garner much voter support.

\section{Thaksin and his Opponents}

Curiously, the major political developments for Thailand in 2011 centre on a figure who has not even spent a day in the kingdom during the year. Former Prime Minister Thaksin has manoeuvred into a position, buttressed by his Pheau Thai Party's undiminished electoral support, where he can now look forward to future opportunities to determine political outcomes. With their justification for the 2006 coup in tatters, and the resounding rejection by the Thai electorate ringing in their ears, the military, bureaucratic, and palace elites who remain so aggressively opposed to his activities have been forced to reconsider their options.

Importantly, during 2011 the notion that some may have overstepped the limits of good judgement with the 2006 coup began to take on ever more coherence. ${ }^{27}$ It has been quietly implied that even the Queen, long regarded as one of the most active anti-Thaksin campaigners, has decided that a more prudent, even conciliatory, approach is needed. Nonetheless, and notwithstanding any anxieties 
that may have developed about the coup, Thaksin remains the most divisive figure in national life, and the level of animosity that his continued political activity generates cannot be underestimated. While 2011 did not see the mass anti-Thaksin protests which featured so prominently in the period 2005-8, there were still many efforts to dent his credibility, especially once it became clear that a Pheua Thai election win was likely. ${ }^{28}$

It is the 2011 election victory which could prove instrumental in the resurrection of his political fortunes. In a highly symbolic move, in October the Yingluck government reissued Thaksin's passport, which had been taken from him in April 2011 by the Democrat-led coalition government. ${ }^{29}$ Since then, prominent Democrat Party spokesmen have called for the impeachment of the Prime Minister and Foreign Minister: they are considered to have abused their powers in reissuing Thaksin's travel document. These efforts to destabilize the government, and disrupt its efforts to reintegrate Thaksin into political life in 2012, are a further indication of the profound and unresolved challenges that Thailand faces. Many anti-Thaksin campaigners still consider him a fugitive from Thai justice: he was sentenced in absentia in 2008 to two years imprisonment for a controversial Bangkok land deal. Furthermore, in May 2010 the Criminal Court issued an arrest warrant after the Department of Special Investigation prepared terrorism charges against Thaksin for his alleged role in the April-May 2010 Red Shirt street protests. ${ }^{30}$ In 2011 there were sporadic efforts to accuse him of terrorism, although by the end of the year the Department of Special Investigation was forced to deny that it had "erased" the relevant Thaksin file. ${ }^{31}$

\section{Military Matters}

In terms of Thaksin's key opponents, it is the senior ranks of the military that have been most unwilling to countenance his increasingly active role. To complicate matters, during 2011 the Thai military faced three major challenges which all required substantial tactical, strategic, and political investments. From the dispute with Cambodia over the Preah Vihear temple complex and surrounding territory, to the ongoing civil conflict in southern Thailand, and the need for resources to be devoted to stewarding political issues in Bangkok's politics, the military had a busy year.

\section{Preah Vihear}

The catalyst for the recent conflict between Thailand and Cambodia is the dispute over the demarcation of the border between the countries in the vicinity of the 
Preah Vihear temple complex. Going back to 2008 there have been periods of heightened tension and occasional clashes between the two countries. However, in early 2011, moves along the border - precipitated largely by domestic political priorities in both Thailand and Cambodia - led to sabre-rattling and then a much more significant level of violence. This conflict with Cambodia saw thousands of Thai troops square off with a sizeable Cambodian contingent. There were a number of engagements in February, and while tensions then eased, there was another major flare-up from April to early May. While the numbers of casualties on the Cambodian side are difficult to verify, around sixteen Thais died in the fighting, with scores wounded.

For the government of then Prime Minister Abhisit Vejjajiva the conflict with Cambodia provided an opportunity to show leadership in the crucial period before the July election. Instead of strengthening popular support, however, the conflict may have served to raise questions about the judgement of the Democratled coalition and its allies in the Thai army. Many Thais were understandably curious about the justification for the showdown and some even queried whether a conflict with Cambodia was in the national interest. Some others no doubt were uncomfortable with the nationalist frenzy which accompanied the effort to challenge a much smaller and weaker adversary. Thai air power, artillery, and armour were always on standby. It was not an episode which reflected well on the government or its diplomatic capacities. It was finally resolved by the election of Yingluck, and also by the intervention of the Association of Southeast Asian Nations, and particularly Indonesia, which held the chair of the regional body in 2011. The Indonesian Foreign Minister, Marty Natalegawa, was especially active in brokering the final truce.

\section{Southern Thailand}

Throughout the year the largest military and security operation has occurred in Southern Thailand. The restive provinces of Yala, Patani, and Narathiwat have seen ongoing fighting between government forces and a range of adversaries. It is often unclear exactly who is fighting and with what purpose. It is now ten years since the most recent period of instability in these provinces began and the Thai Government is seemingly no closer to a resolution, either through a compromise with local residents or through a decisive military or political victory. The prospect of such a victory remains remote because the Thai Government is waging a counter-insurgency campaign under conditions where insurgency is only one, perhaps small, component of the violence. The government 
also faces increasingly well-organized criminal groups, some of whom are apparently collaborating with government security forces. It is a messy situation which defies straightforward analysis.

But the Thai Government or, more precisely, the army seems to have an appetite for almost perpetual deployment. A generation of Thai security officials, from the army, police, and civilian agencies, have now been blooded in the southern conflict. Their efforts to remain engaged are now as much personal and economic as they are tactical or strategic. The conflict has become tied to the prestige, and budgets, of the security forces and they will likely continue to maintain a large presence in the southernmost provinces on an almost permanent basis. A perpetual conflict of this nature is difficult for any government to manage, and especially so for Yingluck whose Pheua Thai Party has little natural political support in the provinces of Southern Thailand.

\section{Bangkok Politics}

For the army leadership, arguably the most important issue in 2011 was the need to be engaged with national politics before and after the July election. Key army generals remain deeply concerned about the potential for Thaksin to destabilize plans for the post-Bhumibol royal succession. As a result, in 2011 General Prayuth continued the army's campaign to remain an active political player, especially regarding the defence of the country's sacred trinity: "nation, religion, king". His statements in the lead-up to the July election were aimed at inserting the military into political discussions and reminding voters of the military's self-appointed role as guardian of morality, Thainess, and royal prestige.

\section{Royal Intrigue}

In 2011 the royal succession was a key, but often unspoken, issue. It is the proverbial elephant in the room for a country which has become accustomed, over King Bhumibol's reign, to the role of a monarchy which continues to influence many political outcomes. The King's health has been a major issue since September 2009, and throughout the years since he has been largely confined to Siriraj Hospital in Bangkok. Milestones, such as the sixty-fifth anniversary of his reign in June and his eighty-fourth birthday in December, were recent opportunities for outpourings of national affection. ${ }^{32}$ Devotional activities have become increasingly fervent, especially as the King's ability to directly influence political events has faded. However, his aura has continued to grow. 
Indeed, as an apparition, hovering somewhere between the living and the dead, he is immensely powerful, with unrivalled symbolic and charismatic potency. It is important to remember that Bhumibol is, after more than six decades on the throne, the only king that more than 92 per cent of the Thai population have known during their lifetimes. ${ }^{33}$ As Andrew Walker has argued, the King's status detracts from the potential for other figures, including those in the palace, to develop their own political personalities. ${ }^{34}$ Thailand faces some decisive months and years now that the fault lines around the future role of the royal family have become increasingly clear. Efforts to buttress the reputation and prospects of individual members of the family continue; although there are many who are clearly not persuaded that the challenges can be easily resolved. ${ }^{35}$

Most worrying, for many observers, is the use of the lèse-majesté law to punish political dissenters. In late 2011 a spate of new cases emerged, and some old cases ended with lengthy prison sentences for those convicted of "defaming, insulting or threatening" senior members of the royal family. One case that provoked particular outrage centred on Ampon "Uncle SMS" Tangnoppakul who was sentenced, in November, to twenty years imprisonment for allegedly sending text messages deemed defamatory. ${ }^{36}$ With such examples, Thailand now faces a future where its international reputation, built on tolerance and a modicum of political plurality, is under threat. ${ }^{37}$ Widespread media reporting highlighted the fearsome deployment of the lèse-majesté law against dissenters and those who, unluckily, become its targets. Internationally, Thailand also faced growing disquiet about the heavy-handed approach to enforcing the lèse-majesté law. To make matters worse, temperate criticism from the United States and United Nations, among others, led to howls of outrage among some pro-monarchy groups.

There is, importantly, still no high level support for efforts to reform the lèse-majesté law and in public there is a chorus of elite backing, even from the Pheua Thai Party, for its continued enforcement. Late in the year, Deputy Prime Minister Chalerm Ubamrung declared that those who call for the reform of the law are bringing on "chaos". ${ }^{38} \mathrm{He}$ even asked, "Don't they have any jobs to go to?" A senior Foreign Ministry spokesman insisted that "the lèse-majesté law is not aimed at curbing people's rights to freedom of opinion and expression nor the legitimate exercise of academic freedom, including debates about the monarchy as an institution". 39

With the cover of such pronouncements, some of the most uncompromising supporters of the lèse-majesté law's continued deployment come from the Pheua Thai government's senior ranks. They clearly see the potential for their own royalist credentials to be bolstered by efforts to target political dissenters, especially those 
on the republican fringe. In this respect, the critical, anti-monarchy sentiments among rank-and-file Red Shirt activists are not always replicated at the highest rungs of Red Shirt/Pheua Thai politics. This is a contradiction which may prove destabilizing as some Red Shirts feel that their leadership does not adequately reflect the interests and priorities for which they fought, and died, in April-May 2010. Indeed, the lèse-majesté crackdowns have another implication for Thai politics. They show that the use of repressive measures is not the monopoly of any one side in the recent conflicts.

\section{Conclusion: Stalemates and Instability}

After the recent years of open political conflict, many Thais are understandably content to see the country's leaders disavow further confrontation. A grand compromise where Thaksin can work with his opponents from the military, royal, judicial, and bureaucratic networks would likely prove very appealing to those millions of Thais who have no stomach for further bloodshed or disruption. ${ }^{40}$ Indications from 2011 are that such an arrangement is slowly taking shape and that the largely pro-royalist public orientation of Yingluck's government has been warmly welcomed by those who worried about the potentially vindictive flavour of pro-Thaksin politicians. This makes outright confrontation between pro- and antiThaksin forces less likely in the short-term. While it opts to take less provocative paths, and disavows more radical Red Shirt proposals, the Yingluck government may be able to steer itself through to the next scheduled election in 2015. In terms of Thai political calculations, that is an eternity. By that time King Bhumibol may no longer be on the throne and many other things will have changed.

In the meantime, we can conclude that 2011 has been yet another tumultuous year. The legacies of recent political battles - all products of the unconsummated efforts of the 2006 coup makers to destroy Thaksin and his popularity - still echo loudly. There is even a call, originating from a controversial group of Thammasat University academics, for the nullification of the legal effects of that coup. ${ }^{41}$ But this is exactly the type of polarizing move which Yingluck has consciously avoided during her first months as Prime Minister. In the final stages of King Bhumibol's lengthy reign, the Pheua Thai government has thus far looked to provide stability without unduly jeopardizing the interests of those palace and military elites who feel threatened by the capacity of Thaksin to disrupt their plans.

But there are now other Thais, heavily politicized by recent conflicts, especially the Red Shirt protests of April-May 2010, who feel that the Yingluck 
government has been insufficiently radical in terms of social and economic policy. Her government could face a republican backlash from those who continue to feel disenfranchised by the politics of the country's leading institutions. ${ }^{42}$ Under these circumstances the threats remain immense, even existential, and the prospect of further calamity or violence is very real. The stalemates between the Thaksin side and the coup makers have already broken on a number of occasions. It is through his electoral success, and talent for populist flourishes, that Thaksin could choose to destabilize, or even destroy, the forces arrayed against him. The year 2011 demonstrated that Thaksin and his juggernaut still mean political business.

\section{Notes}

This article benefits from discussions with many individuals, especially colleagues at the Australian National University, Canberra, but the author bears all responsibility for the final assessments of Thailand in 2011. I would, at the same time, like to offer special thanks to Dr Andrew Walker for his mentorship over many years studying Thai society and politics.

1. In an earlier Southeast Asian Affairs, it was argued that "[i]n medical terms the body politic of Thailand has been really sick since the coup." For further discussion on this metaphorical theme see, Chairat Charoensin-o-larn, "Thailand in 2009: Unusual Politics Becomes Usual”, Southeast Asian Affairs (2010): 303-31.

2. Indeed the Thaksin phenomenon is unique; no other Thai politician has commanded so much popular support nor done so with such consistency over more than a decade.

3. In Thai she is often described as a "nak kan muang na mai" [New face politician]: Thai Rath International News Team, "Newsweek chee 'Yingluck' phunamnamae tae kaengkreang" [Newsweek reports that "Yingluck" is a new face yet unyielding], Thai Rath, 21 September 2011. In English there is a consistent effort to describe her lack of political experience. See, for instance, Thomas Fuller, "A Political Novice Out to Prove She's Her Own Boss", New York Times, 5 August 2011; Lindsay Murdoch, “Tensions Grow as Thailand Awaits Thaksin's Return”, Sydney Morning Herald, 29 December 2011.

4. See, for example, Nattaya Chetchotiros, "Yingluck's Uphill Battle", Bangkok Post, 16 July 2011.

5. For details on this element of the 2011 campaign, see Aim Singpeng, "Vote No" Logic Flawed", New Mandala, 21 May 2011.

6. A banner at a northern Thai political rally from August 2006 captures the sentiment behind Thaksin's long-term support: "however many elections, we (always) vote for the Thai Rak Thai party [Thaksin's original, and now disbanded, political party]". This banner is cited in an eyewitness account of one of the final political rallies 
held by the former Prime Minister before the September 2006 coup: Nicholas Farrelly, "Yes Sir, I Understood", New Mandala, 16 August 2006.

7. In 2011 political scientist Yoshinori Nishizaki published an important analysis of the career of Banharn Silpa-archa, the political titan of Suphanburi. He makes some notable comparisons between Thaksin and Banharn and suggests that they receive popular support "for the same reasons", including their reputations for quick and efficient action to implement local development projects: Yoshinori Nishizaki, Political Authority and Provincial Identity in Thailand: The Making of Banharn-buri (Cornell Southeast Asia Program: Ithaca, 2011), p. 132.

8. Kevin Hewison, "Thailand's Conservative Democratization", in East Asia's New Democracies: Deepening, Reversal, Non-liberal Alternatives, edited by Yin-wah Chu and Siu-lun Wong (Abingdon: Routledge, 2010), p. 134. Pavin Chachavalpongpun, "It's Time the Army Learned to Stay out of Politics for Good", The Nation, 17 August 2011; see also Michael J. Montesano, "Political Conflict in the Advent of Bangkok's 19 September Putsh", in Divided Over Thaksin: Thailand's Coup and Problematic Transition, edited by John Funston (Singapore: Institute of Southeast Asian Studies), pp. 1-26.

9. Pavin Chachavalpongpun, "It's Time the Army Learned to Stay out of Politics for Good", The Nation, 17 August 2011.

10. For a thorough overview of those events and their aftermath, see Human Rights Watch, Descent into Chaos: Thailand's 2010 Red Shirt Protests and the Government Crackdown (New York: Human Rights Watch, May 2011).

11. “PT MP: Cabinet Reshuffle 'Mid-2012”, Bangkok Post, 4 December 2012.

12. Former Prime Minister Thaksin Shinawatra has created three iterations of his political machine. The first was Thai Rak Thai (Thais Love Thais), in power from 2001 to 2006, the second was Phalang Prachahon (People Power), which won an election in December 2007 but was disbanded in 2008, and the third is Pheua Thai (For Thais), which was formed in 2008 and won the 2011 election.

13. Rachel Harvey, "Thai Army Xhief Prayuth Urges Vote for "Good People", BBC News, 15 June 2011.

14. The Thai electoral system has two types of lower house parliamentarians. There are constituency MPs (375 in number) and party-list MPs (125). Usually, candidates who will become senior ministers are put on the party list where their election can be almost guaranteed.

15. Some of the Pheua Thai campaign slogans unapologetically made this point. One suggested "Love Thaksin, Vote for Yingluck" while another argued that "Thaksin Thinks, Pheua Thai Does".

16. In fact, from 2009 to 2010 , Thaksin even served as an economic advisor to the Cambodian Government. The circumstances of his decision to quit that post are somewhat murky. See Supalak Ganjanakhundee, “Thaksin Quits as P Penh's Economic Adviser", The Nation, 24 August 2010. 
17. Supalak Ganjanakhundee, "Yingluck's Charm Goes a Long Way in Indonesia", The Nation, 24 November 2011.

18. "Prime Minister Abhisit Vejjajiva Bids Farewell to the Thai People", Government Public Relations Department, 5 August 2011.

19. Yingluck is Thailand's first female Prime Minister. Some Thai feminists have suggested that they would be delighted to see a female Prime Minister, on the condition they did not carry the Shinawatra name. Indeed, elsewhere in Southeast Asia female politicians have often come to power by drawing on family legacies. In Indonesia, President Megawati Sukarnoputri, daughter of former President Sukarno, is an obvious example. The Philippines saw Corazon Aquino, who was the widow of Senator Benigno Aquino, Jr., become President. Gloria Macapagal-Arroyo is the daughter of a former President of the Philippines, Diosdado Macapagal. And the exemplar of this model in Southeast Asia is Aung San Suu Kyi in Burma. Like Yingluck, she inherits the family's unfinished political business.

20. "Prime Minister Emphasizes the Government's Determination to Foster Reconciliation and Harmonization", Government Public Relations Department, 25 August 2011.

21. While there has been significant attention paid to Yingluck's status as Thailand's first female Prime Minister, it is relevant that of the thirty-six-member Cabinet, only three others are women.

22. Sodchuen Limkriangkrai, "PM Yingluck Failed to Tackle Flood Disaster as Promised, States ABAC Poll", National News Bureau of Thailand, 2 October 2011.

23. World Bank, Thailand Economic Monitor, April 2011.

24. Parista Yuthamanop, "Floods Still Loom Large in Economic Outlook", Bangkok Post, 4 January 2011.

25. Chadamas Chinmaneevong,"Tourism Industry Jittery”, Bangkok Post, 9 January 2012.

26. "Navigating Turbulence, Sustaining Growth", World Bank East Asia and Pacific Economic Update 2011, vol. 2 (November 2011): 77-79.

27. Support for this analysis comes from many sources, but the most comprehensive is Andrew MacGregor Marshall, Thailand's Moment of Truth: A Secret History of 21st Century Siam. In 2011 the first three parts were published online at <http://www. zenjournalist.com/>.

28. David Pilling, “The Ghost of Thaksin Still Haunts Thailand", Financial Times, 15 June 2011.

29. “Thai Foreign Minister Admits Thaksin Passport Revocation Annulled", MCOT, 16 December 2011.

30. “Court Issues Thaksin Terror Warrant”, Bangkok Post, 25 May 2010.

31. "DSI Denies Erasing Thaksin File”, Bangkok Post, 23 December 2011.

32. "Thais Happiest About King's Birthday Celebration, Recovery: Survey”, MCOT, 28 December 2011; Tretip Kamolsiri, "Sounds of Celebration", Bangkok Post, 28 December 2011. 
33. Nicholas Farrelly, "Thailand", in Regional Outlook: Southeast Asia 2012-2013, edited by Michael J. Montesano and Lee Poh Onn (Singapore: Institute of Southeast Asian Studies, 2012), p. 87.

34. Andrew Walker, "Why King Vajiralongkorn Will be Good for Thai Democracy", New Mandala, 23 April 2010.

35. In late 2011, as one example, CNN broadcast a half-hour programme on Thailand and its prospects. The piece was largely framed as a tribute to Princess Sirindhorn, the royal who many Thais reportedly favour for the succession. That CNN programme was criticized online, including in " $\mathrm{CNN}$, the Royalist Trap and the Propaganda Time Warp", Political Prisoners in Thailand, 5 December 2011.

36. “Thailand's Extreme Lese Majeste Law Used to Sentence Another Victim", Political Prisoners in Thailand, 23 November 2011.

37. See Atiya Achakulwisut, "Battle Lines Drawn Over Lese Majeste", Bangkok Post, 31 December 2011; James Hookway, “U.S. Man's Jailing Spotlights Thai Monarch Law”, Wall Street Journal, 9 December 2011.

38. Thomas Fuller, "In Thailand, Support for King Grows Bellicose", New York Times, 23 December 2011.

39. "The Use of the Lèse-Majesté Law in Thailand", Government Public Relations Department, 16 December 2011.

40. One contribution to understanding these dynamics has been introduced under the label of the "Thai Un-State". For details see Craig J. Reynolds et al., "Time's Arrow and the Burden of the Past: A Primer on the Thai Un-State", academia.edu, 7 September 2011.

41. "Nitirat to Push for Coup Nullification and Amendments to Lèse majesté Law in January", Prachatai, 27 December 2011.

42. For a similar argument about how "in their frustration, Ms Yingluck's supporters may turn to more radical groups", see Pavin Chachavalpongpun, "Thailand's False Peace", Wall Street Journal, 29 December 2011. 